\title{
Mitä mieltä, professorit?
}

25 vuoden ikään ehtinyt Aikuiskasvatus kysyi kaikilta aikuiskasvatuksen professoreiltamme heidän näkemyksiään neljässä asiassa. Kaikkiin ei tarvinnut vastata. Tällaista kysyttiin ja näin vastasivat Yrjö Engeström ja Reijo Miettinen Helsingin yliopistosta, Anneli Eteläpelto Jyväskylän yliopistosta, Jukka Tuomisto ja Juha Suoranta Tampereen yliopistosta, Risto Rinne Turun yliopistosta Kari E. Nurmi Lapin yliopistosta sekä vt:nä virkaa hoitava Leena Ahteenmäki-Pelkonen Joensuun yliopistosta. Vastausjärjestys on arvottu.

1. Missä ovat suomalaisen aikuiskasvatustieteen vahvuudet ja valtit nykypäivänä?

2. Millaisiin tutkimuskohteisiin aikuiskasvatustutkimuksen tulisi mielestäsi suuntautua? Onko nyt selkeitä tutkimuksellisia pimentoalueita, joista tiedämme liian vähän?
3. Onko aikuiskasvatustiede ja millä perusteilla itsenäinen tieteenala? Onko sillä ja miksi tieteellistä ja tiedepoliittista merkitystä?

4. Miten Aikuiskasvatus-lehteä tulisi eri yliopistojen horisontista kehittää alan ainoana tieteellisenä julkaisuna Pohjoismaissa?

\section{KARI E. NURMI}

\section{Mistä löytyvät aivotutkimusta ymmärtävät aikuiskasvatustieteilijät?}

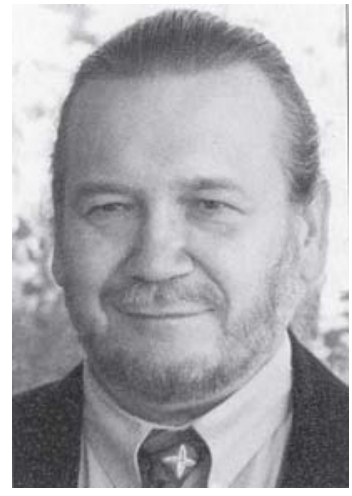

1 Aikuiskasvatustieteessäyhteiskuntatieteellisesti orientoituneella tutkimuksella on suurempi osuus kuin yleisessä kasvatustieteessä, erityiskasvatustieteessä tai opetusteknologiasta mediakasvatustieteeksi kehittyneellä osa-alueella. Se osallistuu vahvasti perustieteiden ja soveltavien lähitieteiden kanssa ammattikasvatuksen, työelämän, korkeakoulu- ja yliopisto-opetuksen sekä vapaan sivistystyön tutkimukseen.

Tutkimuksen pääpaino on ollut kvalitatiivisella puolella, kuten tutkimusalueen suhteellinen uutuus edellyttääkin; avainkysymyksistä löytyy silti myös kvantitatiivista tutkimusta.
Paras osaaminen näyttää olevan oppimisen ja opiskelun tutkimuksessa, jossa myös yhteistyö muiden kasvatustieteiden osa-alueiden kanssa on ollut tiivistä. Työelämän organisaatioiden ja itse työn tekemisen ja siihen liittyvän oppimisen ja asiantuntemuksen tutkiminen ovat olleet hyvin esillä.

Kansainvälisesti olemme kyllä olleet kohtuullisesti näkösällä myös kansalaisvaikuttamisen ja kansalaisyhteiskunnan sivistystoiminnan tutkimuksessa.

2 kyllä kohdealueellamme on valkoista taustaa monin verroin enemmän kuin niitä saarekkeita, joilta löytyy jo kohtuullisesti tutkittua tietoa. Selkeä suuri puute on filosofisen ja teoreettisen tutkimuksen vähäisyys ja pinnallisuus. Kun omien perusteiden erittely ja syntetisointi on paljolti satunnaista lainailua, tulee tutkimuksesta kaiken kaikkiaan helposti amerikkalaisten tai pahimmillaanAmerikan kautta omaksuttujen eurooppalais- 
ten muodikkaiden laina-ajatusten toistelua.

Myös tuolla omalla yhteiskunnallisesti painottuneella kentällämme kasvatuksen suhteuttaminen politiikan ja talouden tutkimuksen teoriaperustaan vaatii todella paljon työtä. Globalisaatio ja mannerten sisäisen yhteistyön lisääntyminen edellyttävät monikulttuurisen kasvatusantropologian vakiintumista myös aikuiskasvatuksen tutkimukseen.

Ihmisen eliniän piteneminen edellyttää geragogiikan kehittämistä ja sen rinnalla toki tarvitaan myös aikuisten inklusiivista erityiskasvatustiedettä.

Kun suuntautumisesta puhutaan, pidän kuitenkin itsestään selvänä, että suuri osa aikuiskasvatuksen tutkimusta tulee jatkossakin kohdistumaan työelämään liittyviin koulutus- ja kehittämistarpeisiin: raha tulee sieltä, missä työ on.

Pidän erittäin todennäköisenä, että lähialueilla tapahtuu merkittäviä läpimurtoja genetiikan, aivotutkimuksen informaatiotekniikan tutkimustulosten seurauksena. On ihan pakko kysyä, mistä löytyvät ne aikuiskasvatustieteilijät, jotka ymmärtävät noita kysymyksiä kylliksi voidakseen soveltaa tietoa myös aikuiskasvatukseen.

Luetteloa olisi helppo jatkaa, mutta tuo edellinenkin osoittanee, että myös priorisointia ja keskittämistä tarvitaan. Meidän alaamme lähellä olevista tutkimuksista on tähän asti jaettu Nobeleita vain, kun tuloksissa on yksilöity kasvatuksen ja talouden välisiä yhteyksiä.

3 Aikuiskasvatustiede ei ole itsenäinen tieteen pääala, vaan osa kasvatustieteitä. Se on soveltava tutkimusalue, kuten lääketieteen, hoitotieteen ja sosiaalipolitiikan osatieteet tai vaikkapa useimmat tekniikan tutkimusalueet. Tiettyä suhteellista itsenäisyyttä sillä toki on: omia journaaleja, professoreita, projekteja, tieteellisiä tutkimusseuroja. Viime aikainen kehitys ei onneksi ole ollut eriytyvää, vaan verkostoitumista korostuvaa.

Parhaimmillaan aikuiskasvatus on kaikkien tieteiden yhteistä perustaa. Joka alalla keskeisenä kysymyksenä on se, miten tieteellistä tietoa levitetään sekä oman alan sisällä että sen ulkopuolella. Kysymys kuuluu tietenkin aikuiskasvatustieteen reviiriin, kun levittäminen suuntautuu aikuisiin. Sen menestyksekäs ratkaiseminen edellyttää, että olemme yhteistyössä alojen omien didaktikkojen kanssa - vaikea diplomaattinen ongelma, koska he eivät tietenkään luovuta tiedon omistajuutta meille ja haluavat kunnian myös sen levittämisestä.

Tehtävä edellyttää aina yhteistyötä myös kommunikaatiotieteilijöitten kanssa. Ongelman osittaisillakin ratkaisuilla on hyvin keskeinen tiedepoliittinen merkitys, oli niissä mukana minkä tieteenalan edustajia tahansa. Osallistuessaan tähän yhteiseen tehtävään aikuiskasvatustieteilijät (mikä sanahirviö) aina osallistuvat samalla myös sekä tiedepolitiikkaan että laajempaankin yhteiskuntapolitiikkaan: kasvatus on olemukseltaan aina politiikkaa.

Onko sillä, mitä olen tehnyt tutkiessani mediakulttuuria, aktiivisten kansalaisten elinikäistä oppimista, kentän aikuiskasvatusinstituutioiden suuntautumista, tavoitteita ja innovaatioita, yliopisto-opiskelijoiden motivaatiota ja opintokokemuksia, yrittäjyyskasvatusta, kuluttajakasvatusta opettajankoulutuksessa tai kirkon uudistamista, ollut merkitystä?

En tietenkään olisi tutkinut, ellen olisi merkitykseen uskonut, mutta tutkijan on myös alistuttava historian tuomioon. Kasvatustieteiden yhteisenä, kaiken nielevänä heikkoutena on KM:n, siis tiedon hallinnan, takapajuisuus ja osittainen puuttuminen. Mistä kirjastosta tai tietokannasta saa tiedon siitä, mitä juuri nyt on tutkittu, mitkä tutkimustulokset on varmistettu, mitä kasvatustieteissä varsinaisesti tiedetään? Missä kirjataan kasvatuskäytänteitä koskevat patentit?

Mieleen palautuvat folkloristiikan professori Salmisen lausumat suomalaisesta kansanperinteestä ja sen tutkimuksesta viime vuosisadan alkupuolelta. Edellisestä hän kuuluu todenneen: "Lainaa, lainaa ja taaskin lainaa!" ja jälkimmäisestä: "Suomalaisesta kansanrunoudesta on tutkittu vain kymmenen prosenttia ja sekin päin helvettiä."

4 Kysymykseen on jo kätketty valmiiksi vastauksia. Jos se haluaa olla tieteellinen, sen on saatava käyttöönsä pelkkää aikuiskasvatustiedettä laajemman aikuiskoulutustutkijoitten ammattikunnan tarjoama monitieteinen panos. Jos se haluaa säilyttää kentän lukijoiden mielenkiinnon, sen on syytä tarjota entistäkin selkeämmin teoreettisesti perusteltuja ja käytännössä toimivia tieteellisiä ratkaisuja kentän suuntaan.

Jos lehti on ainoa, sitä pitää levittää mahdollisimman laajalle. Se edellyttää ainakin kahta asiaa. Ensinnäkin lehden kielipolitiikkaa pitää ta- 
valla tai toisella saada monipuolisemmaksi. Suomenkielisyys muodostaa ehdottoman esteen lehden laajemmalle leviämiselle. Ensimmäisenä harkitaan varmaan ruotsinkielisen ja englanninkielisen julkaisemisen mahdollisuuksia, mutta asiantuntijoita ja markkinoita on ainakin kaikilla lähialueiden suunnilla, mietittäköön siis myös
Baltian, Puolan ja Venäjän kielten asemaa lehden julkaisupolitiikassa.

Toiseksi lehden julkaisemismuotoja pitää kehittää. Vain internet tuo lehden aidosti mahdollisimman monen käyttäjän ulottuville, mitä paremmin sitä päästään hyödyntämään, sitä paremmin lehti palvelee myös yliopistomaailmaa.

\section{RISTO RINNE}

\section{Tutkimuksellisia katvealueita löytyy}

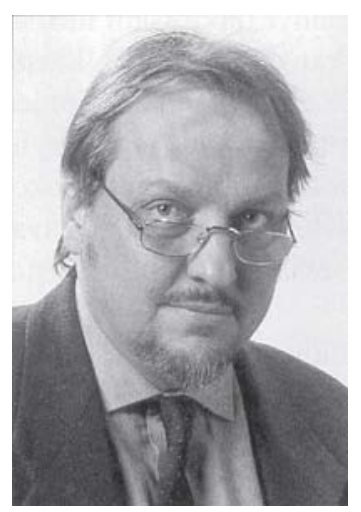

1 Vahvuudet ja valtit ovat monia muita tieteitä laajemmassa inhimillisessä ja sosiaalisessa ymmärryksessä; pitkässä pohjoismaista tasa-arvoisia elämänmittaisia koulutusmahdollisuuksia painottavassa historiallisessa perinteessä; siinä, ettei tiede ole vielä tyystin alistunut tutkimusintressiltään tekniseksi insinööritaidoksi ja palvelemaan ainoastaan lyhyen tähtäimen kilpailun ja työelämän vaatimuksia; tiedekentän laajuudessa ja monimuotoisuudessa

2 Entistä vahvemmin tulisi suuntautua aikuiskasvatussosiologisiin, koulutuspoliittisiin ja kansainvälisesti vertaileviin merkittäviin tutkimushankkeisiin. Etenkin vertaileva aikuiskoulutustutkimus on hyvin heikoissa kantimissa. Muita katvealueita ovat "elämänkestoisen koulutushaluttomuuden" tutkimuskenttä, ikääntyvien ihmisten ja ikääntyvän väestön oppimistarpeet sekä koulutuksen elämänmittaisen merkityksen tarkastelut sosiaalisen, kulttuurisen sekä taloudellisen pääoman viitekehikossa. Eri väestöryhmien elämänikäisen ja -laajuisen oppimisen eroavuudet ja vaikutukset ovat erilaisista osallistumistutkimuksista huolimatta kaltevalla alustalla. Myös työssäja arjessa oppiminen on heikossa asemassa.

3 Tieteiden raja-aidat ovat historiallisesti muuntuvat ja veteen piirretyt. Aikuiskasvatustiede on itsenäinen tieteenala siinä määrin, kuin jokin tieteenala yleensä on, esimerkiksi sosiaalihammas- lääketiede tai elokuvatiede. Sillä on monessa muita enemmän; oma kohdealue, omat tieteelliset julkaisusarjat, omat oppituolit ja omat laitokset ja julkaisusarjat. Sillä on oma tutkimuskohde, osittain oma tutkimusote, mutta toki sen tieteenperusta kytkeytyy metodologisesti ja paradigmaattisesti sekä näkökulmiltaan ja kysymyksenasettelultaankin historiallisesti mitä syvimmin yleisemmin yhteiskuntatieteisiin ja humanistisiin tieteisiin. Ja näin on hyvä.

4 Aikuiskasvatus-lehti on ollut piristävä ja aikaansa hyvin seuraava poikkeus monien harmaiden tieteenalajulkaisujen joukossa. Artikkelien lisäksi myös kirja-arvostelupalsta, keskustelupalsta ja ajankohtaisuutiset täydentävät kokonaisuutta hyvin. Kiitos tästä kuulunee oiville päätoimittajavalinnoille ja toimitukselle.

Mutta välillä lehdessä haittaa liiallinen populaarisuus ja ajoittainen kepeys mm. muodon ja kirjoittajakuvien ilmentämänä. Lisäksi minua häiritsee välillä joidenkin artikkelien liiallinen käytäntö-ja ammattilähtöisyys sekä suoranainen utilitaristisuus, mikä lienee vuosien saatossa vain lisääntynyt. Myös tiettyä sensuuria liiallisen suoria ja radikaaleja artikkeleita kohtaan saattaa olla ilmennyt menemättätässä syvemmälle.

Välillä mukaan mahtuu myös liiaksi tekoviisaita kirjoituksia. Ehkä kaipaisinkin lehdeltä vielä vakavampaaja syvempää otetta sekä suorastaan välillä raskautta. Keskusteluosastojakin voisi jämäköittää vahvemmin vastaväitöksin tärkeistä aiheista. Teemanumeroissa niiden päätoimittajan panoksen tulee olla vaativa ja painava.

Aikanaan yritettiin toimittaa pohjoismaista englanninkielistä Adult Education -lehteä, mutta sen kesto jäi lyhyeksi. Epäilemättä tuollaista lehteä tarvittaisiin yhä enemmän. 


\section{Ongelmien ja innovaatioiden sisältö- tuntemus on oppimishaasteiden ymmärtämisen edellytys}

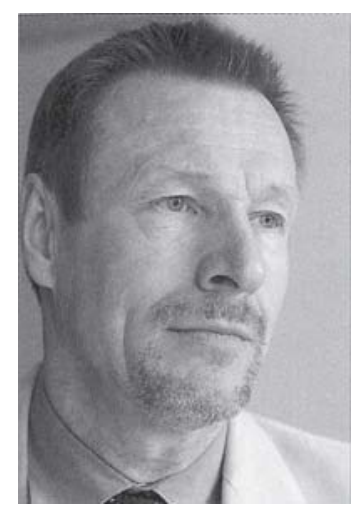

1 suomalaisen aikuiskasvatustieteen potentiaalinen vahvuus on omaperäisten teorian ja aidon käytännön välisessä vuoropuhelussajayhteistoiminnassa - sellaisessa, jossa molemmat kehittyvät. Tämä on tosiaan potentiaalinen vahvuus; se realisoidaan vain määrätietoisella ponnistelulla ja paradigma- sekä tieteenalarajat ylittävällä yhteistyöllä.

2 Tutkimusta tulisi voimakkaasti suunnata suurten ja hallitsemattomien yhteiskunnallisten ongelmien ja innovaatioiden synnyttämiin oppimishaasteisiin ja tapoihin ottaa näitä hallintaan uusilla oppimisen teorioilla ja käytännöillä. Tällaiset uudet ongelmat ja kohteet ulottuvat ilmastonmuutoksesta uusiin kulkutauteihin, ihmiskaupasta Internet 2.0:aan, bioteknologiasta avoimen lähdekoodin tietojärjestelmiin. Näiden synnyttämiä oppimishaasteita ei voi ymmärtää paneutumatta itse ongelmien ja innovaatioiden sisältöön, mikä taas on mahdollista vain aikuiskasvatustieteilijöiden ja sisältöihin erikoistuneiden asiantuntijoiden yhteistyössä.

3 Tieteenalojen itsenäisyys on suureksi osaksi keinotekoinen jäänne ja myytti. Totta kai aikuiskasvatustieteellinen näkökulma on arvokas ja sen tulee kehittyä omista lähtökohdistaan, mutta linnoittautumisen ja eristymisen asemasta tarvitaan avautumista ja mukaan menemistä.

4 Edellä esitetyt suunnat tulisi ottaa vahvasti harkintaan artikkeleiden ja teemanumeroiden hankinnassa. Ei missään tapauksessa tule hakea populaarisuutta tutkimuksen kurinalaisuuden ja syvällisyyden kustannuksella. Olisi omistettava pitkällä aikavälillä valmisteltavia teemanumeroita nouseville aiheille, joissa myös uutta luova teoretisointi ja metodologian kehittely pääsevät esille.

\section{Verkoissa tapahtuva hajautettu oppiminen on haaste}

2 voin mainita ainakin on kaksi aluetta, jotka ovat tärkeitä.

Ensinnäkin oppimisesta on tullut yhteiskuntapoliittisen kielenkäytön keskeinen sana. Taloustieteilijät sanovat, että elämme oppivassa yhteiskunnassa ja että uuteen tietoon ja teknologiaan ja toimintatapoihin perustuvat innovaatiot ovat kansakunnan kilpailukyvyn ja hyvinvoin- nin tärkein ehto. Innovaatiotutkijat ja organisaatiososiologit puhuvat oppimisen verkoista sekä osaamisen ja kykyjen kehittämisestä. Liiketaloustieteessä keskeisiksi tutkimuksen ja johtamisen alueiksi ovat muodostuneet "organisaation oppiminen" ja "tiedon johtaminen." Pääministeri Matti Vanhasen huhtikuussa 2006 asettaman Alueellisen yritys- ja innovaatiotoiminnan sel- 


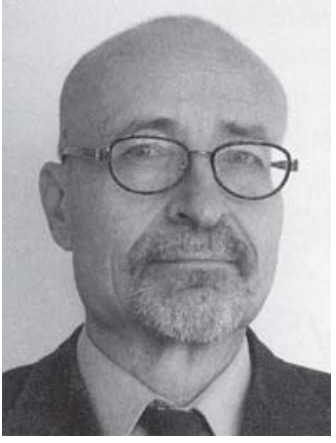

vitysmies julkisti mietintönsä "Vaurastuminen kansallisena velvollisuutena" 18. lokakuuta 2006. Keskeisin toimenpidesuositus on innovaatio- ja osaamispolitiikkaohjelman käynnistäminen seuraavan hallituskauden alussa.

Tällä politiikan kielenkäyttöön omaksutulla sanastolla ei ole systemaattisesta kytkentää kasvatustieteellisiin tai psykologisiin oppimisteorioihin. Tästä seuraa, että voidaksemme antaa panoksemme oppimista yhteiskunnassa koskevan keskusteluun, meidän olisi kyettävä arvioimaan kriittisesti tätä keskustelua ja tarjoamaan keskusteluun oma uskottava vaihtoehtomme ja panoksemme. Siksi aikuiskasvatustieteilijöiden on kyettävä käymään vuoropuhelua talous- ja liiketaloustieteilijöiden sekä organisaatio- ja innovaatiotutkijoidenkin kanssa.

Oppimisen psykologisen ja kasvatus- ja koulutussosiologisten teorioiden ohella on tunnettava näillä alueilla tapahtuvaa teorianmuodostusta ja tieteellistä keskustelua. Aikuiskasvatustieteestä tulee entistäkin selvemmin monitieteinen.

Toiseksi ja edelliseen liittyen, olisi ymmärrettävä paremmin informaatioteknologiaan perustuvan yhteiskunnallisen muutoksen mahdollisuuksia ja vaatimuksia. Kysymys ei ole pelkästään teknologiaan perustuvien oppimisympäristöjen kehittelystä koululaitoksessa, ammatillisessa koulutuksessa ja korkeakouluissa. Internet ja tietotekniset työvälineet synnyttävät kokonaan uusia tapoja tehdä asioita. Esimerkkinä on vaikkapa vapaaehtoisten vuonna 2001 perustama Wikipedia verkkotietotosanakirja, johon kuka tahansa voi kirjoittaa hakusanoja ja jota käyttäjät ylläpitävät tiettyjen pelisääntöjen mukaan.

Sen kehitys tietoyhteiskunnan keskeiseksi työvälineeksi on ollut hämmästyttävä. Vuoden 2003 alussa englanninkielisessä Wikipediassa oli 138000 hakusanaa, kesällä 2005 niitä oli 1,6 miljoonaa.

Wikipediaa voivat käyttää kaikki, joilla verkkoyhteys. Wikipedialla on ylivoimaisia ominaisuuksia verrattuna perinteiseen tietosanakirjaan. Se päivittyy erittäin nopeasti. Se kattaa perintei- siä tietosanakirjoja paremmin uudet tapahtumat, ilmiöt ja kehityskulut. Se ohjaa lukijaansa uusimman tiedon äärelle. Kun hakee vaikkapa sanan "tiedon louhinta" (data mining) ei saa pelkästään lyhyttä ja tiivistä esitystä asiasta, vaan myös viittaukset tärkeimpiin viimeaikaiseen asiaa käsitelleisiin tieteellisiin artikkeleihin tai teoksiin. Wikipedia on samalla itse esimerkki uudesta ilmiöstä, internetvälitteisestä hajautetusta luomisesta, josta on tulossa yhä tärkeämpi ilmiö eri elämänaloilla.

Verkostoissa tapahtuvan ja hajautetun oppimisen ja luomisen internet- ja tietoteknisten välineiden ja (kuten uusiutuvien ja hajautettujen tietokantojen ja platformien) rakentaminen ja käyttö eri yhteiskunnan toiminnan alueilla ja organisaatioissa on yksi haaste aikuiskasvatustieteelliselle tutkimukselle.

3 Mielestäni aikuiskasvatustieteellä ei ole kovin vahvaa, yleisestä kasvatustieteestä eroaavaa teoreettista perustaa, vaikka erityisiä aikuiskasvatustieteellisiä teorioita onkin esitetty.

Tärkeimmät erot yleiseen kasvatustieteeseen lienevät tutkittaviin ilmiöihin liittyviä. Yleinen ja sovellettu kasvatustieteen perinteinen tutkimuskohde on ollut lasten oppiminen koulussa, mistä syystä kehityspsykologia ja lasten kehitystä koskeva tutkimus on ollut sille keskeisempi kuin aikuiskasvatustieteelle.

Aikuiskasvatustiede, kuten yleinen kasvatustiedekin, rakentuu viime kädessä perustieteiden, siis filosofian, sosiologian, psykologian kehityksen tarjoamalle perustalle, joka koostuu itsessään kilpailevista teoreettisista näkemyksistä ja koulukunnista. Nämä eri resurssit olisi aikuiskasvatustieteellisessä opetuksessa tuotava hyvin ja ajanmukaisesti esiin.

Työssä tapahtuvan oppimisen tutkimuksessa yhä tärkeämmäksi tulee liiketaloustieteellisen, tiedon sosiologia sekä organisaatiotutkimuksen ja innovaatiotutkimuksenkin teorioiden ja osaamisen tunteminen. Ne hallitseva oppimisesta ja yhteiskunnan muutoksesta käytävää keskustelua. Toisaalta niiden käsitykset oppimisesta ovat rajoittuneita.

Aikuiskasvatustieteellä tulee olemaan tieteellistä ja tiedepoliittista merkitystä siinä määrin, kuin se pystyy tarjoamaan varteen otettavan vaihtoehdon näiden mainittujen alojen jäsennystavoille ja tällä tavalla ottamaan aloitetta oppimistayhteiskunnassa koskevassa keskustelussa. 
4 Lehti on tehnyt uraa uurtavaa työtä ja vakiinnuttanut paikkansa keskeisenä suomalaisen aikuiskasvatustieteen instituutiona. Kuten jokaisen suomalaisen tieteellisen aikakauslehden osalta, suomea puhuva tutkijayhteisö kun on pieni, jatkuva tehtävä on lehden tieteellisen tason ja ajankohtaisuuden turvaaminen. Tämä tehtävä on sovitettava yhteen sen kanssa, että käytännön aikuiskoulutustyössä olevat lukevat lehteä laajasti.

\section{Aikuiskasvatustieteemme on kansain- välisinkin mittarein korkeatasoista}

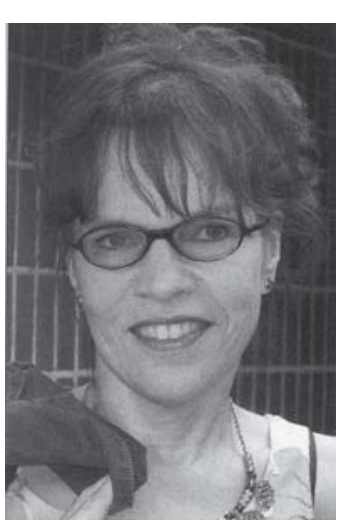

1 suomalaisen aikuiskasvatustieteen vahvuudet ovat alan tutkimuksen elinvoimaisuudessajauusiutumiskyvyssä. Teoreettinen keskustelu on vireää ja monimuotoista, osallistumme myös ilahduttavan vilkkaasti alan kansainväliseen keskusteluun. Alan tutkijoiden kasainvälinen verkottuminen sekä paradigmojen ja metodisten lähestymistapojen rikkaus on myös merkittävä vahvuus. Tosin pienen maan vaarana on helposti myös kulloisenkin vallitsevan muotiteorian pinnallinen ja kritiikitön jäljittely ilman, että löytyi uskallusta argumentoida myös vaihtoehtoisten lähestymistapojen puolesta.

Meillä tehdään kuitenkin tänä päivänä kansainvälisenkin mittapuun mukaan korkeatasoista aikuiskasvatustiedettä ja osallistutaan merkittävällä panoksella niin pohjoismaiseen, eurooppalaiseen kuin maailmanlaajuiseen keskusteluun aikuiskasvatustutkimuksen eri osa-alueilla. Tutkimus kohdistuu yhtä hyvin elinikäisen oppimisen, ammatillisen aikuiskoulutuksen kuin vapaan sivistystyön ja aktiivisen kansalaisuuden tukemisen ongelmiin. Suomalainen aikuiskasvatustutkimus on myös hyvin vaikuttavaa siinä mielessä, että tutkimuskysymykset nousevat ajankohtaisista yhteiskunnallisista haasteista. Käytämme myös runsaasti sellaisia lähestymistapoja ja metodeja (esim. toimintatutkimus, osallistava etno- grafia, narratiivinen ja biograafinen lähestymistapa), joiden avulla rakennamme ekologisesti validia tietämystä ja osallistumme aikuiskasvatuksen käytäntöjen kehittämiseen. Havaitsin tämän taas kerran osallistuessani pari viikkoa sitten EARLIn 'Learning and Professsional Development' SIG:in kongressiiin Hollannissa.

Jos aikuiskasvatustutkimuksen valttikortteja lähtee etsimään, ensimmäisenä tulee mieleen ikioma tieteellinen aikakauslehtemme Aikuiskasvatus. Myös Kansanvalistusseuran ja Aikuiskasvatuksen tutkimusseuran kustantama Aikuiskasvatuksen vuosikirja on samaa sarjaa. Vuorittain järjestettävät Aikuiskasvatuksen tutkimuspäivät ovat alamme merkittävä keskustelufoorumi, joka vahvistaa aikuiskasvatustieteen identiteettiä ja tutkimuksesta käytävää keskustelua.

2 Aikuiskasvatustutkimuksen tulisi mielestäni suuntautua monipuolisesti aikuisten kasvun, osallisuuden ja identiteettien rakentamisen kentille. Erityisen haasteellisena näen tänä päivänä aikuisen identiteetin rakentamisen dilemmat: miten yksilöllisyyteen ja itse itseään auttavaan kansalaisuuteen nojaavassa kilpailullisessa ja narsistiseen eetokseen nojaavassa kulttuurissa ylläpidetään yhteisöllistä, generatiivista ja viisasta aikuisuutta. Kasvatus, varsinkaan aikuisuuteen liitettynä ei ole muodikasta - huolimatta siitä, että tänä päivänä aikuisuuden rakentamisen kentät kuten työ, perhe, ihmissuhteet ja muu elinympäristömme edellyttää aikuisilta jatkuvaa itsensä uudelleen määrittelyä. Elinikäisen oppimisen, yksilöllisyyden ja itseohjautuvuuden rinnalle tarvitaan myös entistä parempaa ymmärrystä ihmisen elämänkuluista, identiteeteistä, subjekteista ja siitä, 
miten tukea ihmisten aktiivisesta toimijuutta hyvän ja mielekkään elämän puolesta.

Aikuisuuden rakentuminen ja sen rakennusainekset ovat viime vuosina muuttuneet, eikä esimerkiksi ydinperheen perustamista, lasten hankkimista tai vakituista työpaikkaa voida enää itsestään selvästi pitää aikuisuuden rajapyykkinä. Ajassamme on myös runsaasti sellaista lasten ja nuorten pahoinvointia, joka herättää kysymyksen, miten kasvetaan aikuisuuden edellyttämään vastuunottoon vanhemmuudesta, parisuhteestaja yhteiskunnallisista ongelmista.

Työelämän paineet ovat jatkuvasti lisääntyneet, mikä vaikeuttaa työn ja muun elämän yhteensovittamista. Globaalin markkinatalouden synnyttäminä arvoina korostuvat lyhyen tähtäimen kilpailu, epävarmuus, pätkätyöt, vaatimus jatkuvista näytöistä ja ylityöt. Jos yhteiskunnassa vallitsevana on itsekseen pärjäämisen eetos ja yksin työnsä ja elinikäisen oppimishaasteensa kanssa selviytyminen, ei ole lainkaan hämmästyttävää, että mielenterveysongelmat ovat tärkein työkyvyttömyyseläkkeelle jäämisen syy.

Työelämän vaativuus heijastuu armottomimmin niihin ryhmiin, jotka ovat haavoittuvimpia: yksinhuoltajat, pienten lasten vanhemmat sekä yleensäkin taloudellisten, sosiaalisten ja kulttuuristen yhteisöjen ja verkostojen ulkopuoliset ihmisryhmät. Sosiaalisten turvaverkkojen puutteessa elävä, pienpalkkaisia pätkätöitä tekevä tai työmarkkinoiden ulkopuolelle joutunut yksinhuoltaja, joka vielä kärsii alkoholiongelmista, tuottaa myös seuraaville sukupolville kasvuympäristöjä, joista silmiämme avaava ajankohtainen kuvaus on meillä televisiossakin nähty Kreetta Onkelin Ilonen talo.

Puhe elinikäisestä oppimisesta työelämässä on vilkasta. Ajankohtaiset tutkimukset (Kaija Collin, Kati Tikkamäki) osoittavat kuitenkin, että työssä oppimisen mahdollisuudet ovat entisestään kaventuneet työtahdin kiristymisen ja kiireen seurauksena. Samalla kun puhutaan entistä enemmän jaetusta osaamisesta, oppivista tiimeistä, sitä vähemmän työympäristöissä näyttää olevan mahdollisuuksia oppimiseen ja yhteisöllisyyteen. Julkisella sektorilla vallitseva 'new public management' on myös kaventanut perinteisiä professionaalisen autonomian mahdollisuuksia ja tuonut sen tilalle yksityiseltä sektorilta lainattuja tuloksellisuus- ja palkkausmalleja.

Tässä tilanteessa tarvitaan uudenlaista työn ja koulutuksen välisten suhteiden määrittelyä, jos- sa lähtökohdaksi otetaan myös nuoren ja aikuisen laaja-alainen kasvu ja kehitys inmisenä - ei siis pelkästään työelämän välittömät vaatimukset. Tällainen työntekijän suojelu on tarpeen kaikilla aloilla, mutta erityisesti luovassa ja inmiskeskeisessä työssä, jossa oppiminen ja uusiutuminen merkitsee oman työidentiteetin uudelleen määrittelyä. Identiteettiä koskettava työssä oppiminen ei ole mahdollista, mikäli työssä ei ole tarpeeksi tilaa ja aikaa uusiutumiselle.

Laajemmin olen tarkastellut aikuiskasvatuksen ajankohtaisia tutkimustarpeita virkaanastujaisesitelmässäni, joka on julkaistu Aikuiskasvatus-lehdessä 2 /2005, 150-154.

3 Aikuiskasvatustiedettä voidaan pitää itsenäisenä tieteenalana, jos itsenäisyyden kriteereinä ovat alan oppituolien, tieteellisten aikakauslehtien ja kansainvälisten kongressien sekä luonnollisesti omaleimaisen elävän tutkimusperinteen olemassaolo. Tieteenalan kehityksestä ja jatkuvuudesta kertovat myös tohtorikoulutettavat sekä tieteelliset yhteisöt ja seurat.

Eriasia on, mikä on aikuiskasvatustieteen identiteetti ja asema suhteessa lähitieteisiin. Aikuiskasvatusta voidaan pitää kasvatustieteellisenä oppiaineena, joskin se aikuisuuden elämänkenttiä tarkastellessaan on lähempänä yhteiskuntatieteitä kuin muut kasvatustieteen osa-alueet. Itsenäisyys ei luonnollisestikaan tulisi merkitä itseriittoisuutta tai eristäytymistä suhteessa lähitieteisiin. Kasvatustiede tai aikuiskasvatus pääaineenaan valmistuvat maisterit, joilla ei ole opettajankoulutusta, sijoittuvat pääosin aikuiskoulutuksen kentille esim. yliopistoihin ja korkeakouluihin.

Maisterikoulutuksen saaneista monet hankkivat tänä päivänä opettajakelpoisuuden, jonka tuottaa esimerkiksi Jyväskylän yliopistossa kasvatustieteen laitoksella järjestettävät aikuiskouluttajan pedagogiset opinnot (APO). Tämä aikuispedagogiikan periaatteille rakentuva opettajankoulutus erottuu opetussuunnitelmaltaan ja toteutustavoiltaan selkeästi muusta opettajankoulutuksesta ainakin meidän yliopistossamme.

Aikuiskasvatuksen tieteelliseen merkitykseen viittasin jo edellä. Tiedepoliittinen merkitys näkyy aikuiskasvatukselle ja koulutukselle asettuvista yhteiskunnallisista haasteista. Tällaisia ovat elinikäisen oppimisen vaade, työelämän ja työurien muutokset ja teknologian kehitys. Lisäksi aikuiskasvatukseen kohdistuu haasteita kansain- 
välistymisen edistämisestä, terveyden ja hyvinvoinnin ylläpidosta, aktiivisen kansalaisuuden tukemisesta, pahoinvoinnin ja syrjäytymisen ehkäisystä sekä yhteiskunnallisen eheyden ja tasaarvon vahvistamista sekä väestön ikääntymisen huomioonottamisesta. Aikuiskasvatukselta odotetaan siis tukea ajankohtaisten yhteiskunnallisten muutosten edistämiseen, mutta samanaikaisesti myös lääkkeitä muutoksista aiheutuvien ongelmien hoitamiseen.

Yhteiskunnallisessa keskustelussa aikuiskoulutus nähdään ratkaisuksi jo vähän liiankin laajalti: lähes kaikkiin yhteiskunnallisiin ongelmiin. Siinä missä presidenttimme Tarja Halonen Al Jazeera-kanavalla kuvasi maamme menestyksen kolmea tärkeintä ainesta 'education, education and education', ajankohtaisessa globalisaatiota, työmarkkinoita ja koulutusta koskevassa puheessa ratkaisuksi nähdään toistuvasti 'Adult Education, Life-long learning' ja 'Work-based learning'.

Aikuiskasvatuksen tiedepoliittisesta yhtä hyvin kuin työmarkkinakoulutus- ja sosiaalipoliittisesta painoarvosta ei siis pitäisi olla puutetta.
Pikemminkin pitäisi jo realistisesti ajatella, että yksin koulutuksella ei voida ratkaista ihan kaikkia yhteiskunnassa ja inmisten elämässä olevia ongelmia.

4 Aikuiskasvatuslehteä tarvitaan yliopistojen näkökulmasta korkeatasoiseksi tieteellisen keskustelun foorumiksi. Yliopistoissa vallitseva paine julkaista artikkeleita oman alan referoidussa tieteellisessä aikakauslehdessä tullee suuntaamaan painetta myösAikuiskasvatus-lehteen. Mielestäni lehden päärunkona tulisikin olla korkeatasoiset tieteelliset artikkelit. Korkeintaan 1-2 lehteä vuodessa voisi olla teemanumeroita, mutta sivumäärällisesti eniten palstatilaa tulisi tarjota avoimen kilpailun perusteella aikuiskasvatustieteen eri alojen artikkeleille. Näin vältetään myös se, että lehdestä tulisi liian pienen piirin keskustelukenttä. Ajankohtaisille tieteellisille tapahtumille (kongressit, seminaarit, väitökset, virkaanastujaiset) tulisi myös olla tilaa, samoin luonnollisesti kirja-arvosteluille.

\section{Teoreettinen tutkimus juuttunut totuttuihin jakoihin}

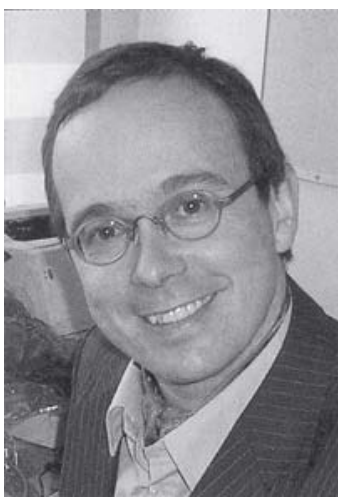

1 Aikuiskasvatukseksi laskettava tutkimus on laajassa katsannossa hurjan monipuolista sikäli, että siihen liittyvää tutkimusta tehdään monilla lähitieteenaloilla. Tällainen monitieteisyys on vahvuus, jota pitäisi entisestään vahvistaa paitsi siksi, että aikuiskasvatus voi tieteenalana kehittyä, myös siksi, että aikuiskasvatuksen pääaineopiskelijat voivat löytää työtilaisuuksia myös lähitieteenalojen tutkimusympäristöistä.

Aikuiskasvatuksen tutkimusta harjoittavien laitosten tutkimuskiinnostukset ovat viime vuo- sina selvästi eriytyneet, ja on syntynyt aiempaa selvempiä tutkimussuuntauksia. Tähän liittyen ollaan myös edetty alan kansainvälisen tutkimuksen etulinjoille. Tällainen monitieteinen ja kansainvälinen liikehdintä on tärkeätä.

2 Teoreettisesti tutkimus on ehkä liiaksi kiinnittynyt kuluneisiin jakoihin kuten työelämä ja vapaa sivistystyö tai teoreettinen ja käytännöllinen. Tarvitaan lisää sellaisten kohteen mukaisten käsitteiden kehittelyä, jotka palvelevat alan yleistä teoreettista kehittämistä. Lisäksi alan tutkijoiden tehtävä on ravistella erilaisia vakiintuneita käsityksiä aikuisten oppimistoiminnasta ja sen yhteiskunnallisista ehdoista.

Pimentoalueita, joita omalta osaltani yritän valaista, ovat toisaalta aikuiskasvatuksen 'ideologiakriittinen' tutkimus, joka antaa aikuiskasvatuksen tutkijoille ja käytännön toimijoille yh- 
teiskuntateoreettisia ymmärrysvälineitä ja toisaalta etnografistyyppiset tutkimusmenetelmät "maanläheisinä" lähestymistapoina ihmisen toiminnan tutkimuksessa.

3 Ajattelen yhteiskuntatieteet, mukaan lukien kasvatustieteet, ikään kuin kaikkien yhteiskunnan ja kasvatuksen tutkijoiden yhteiseksi lähteeksi, jota jokainen voi käyttää viljelysmaillaan. Liian korkeat tiedepoliittiset raja-aidat haittaavat tutkijoiden vuoropuhelua. Tiedepoliittista merkitystä aikuiskasvatuksella on sikäli, kun sen parissa työtään tekevät tutkijat omaksuvat "osallistuvan tieteen" ajattelutavan ja mieltävät itsensä 'julkisiksi intellektuelleiksi'. Tämä tarkoittaa sellaisten tiedon muotojen kehittelemistä, joissa annetaan arvoa ihmisille ja heidän kohtaamalleen todellisuudelle teknokraattien ylpeydenai- heekseen nostamaa abstraktia ja silvottua todellisuutta vastaan.

4 Keskeinen kehittämisen kohde on lehden verkkoversio. Ehdottaisin vanhojen lehtien lataamista verkkoon tutkijoiden ja muiden käyttöön sekä esimerkiksi Yhteiskuntapolitiikka-lehden käytäntöä, jossa myös uudet lehdet tulisivat verkkoon tietyllä, esimerkiksi vuoden viiveellä vaikkapa. Tämä kannustaisi hyödyntämään lehden aineistoja entistä enemmän myös aikuiskasvatuksen ja lähialojen yliopisto-opetuksessa. Huomaan, että opiskelijoita tulee entistä enemmän patistettua verkkolehtien pariin, mutta yhä harvemmin kirjastoon penkomaan paperiversioita. Saman toimintatapojen muutoksen on kokenut omassatyössä.

\section{Inhimillisemmän yhteiskunnan ja työelämän rakennusaineksia}

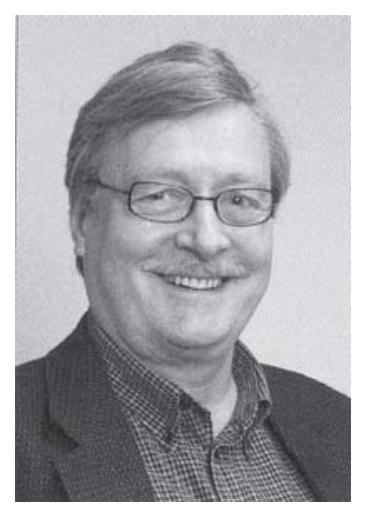

1 suomalaisen aikuiskasvatustieteen ja tutkimuksen vahvuudet lepäävät sen vahvassa traditiossa, tutkimuksen monipuolisuudessaja laajassa kansainvälisyydessä

Aikuiskasvatuksen yliopistollisella opetuksella on maassamme pitkät perinteet.

Zachris Castrénhan aloitti kansansivistysopin opettamisen tuntiopettajana YKK:ssa jo vuonna 1929. Vain Yhdysvalloissa ja Englannissa aikuiskasvatus yliopistollisena oppiaineena alkoi yhtä varhain. Oli onni, että ensimmäinen opettaja oli heti alusta lähtien tieteellisesti orientoitunut ja laaja-alaisesti perehtynyt niin filosofiaan kuin muihin tiedealueisiin, jotka eivät olleet vielä tuolloin kovin pitkälle kehittyneet.

Castrén totesi jo vuonna 1930, että alan omien perusteiden, historian ja menetelmien tuntemuksen lisäksi opiskelijoiden pitäisi perehtyä yhteiskunta-, valtio- ja taloustieteellisiin aineisiin. Hän toivoi, että korkeakoulu laajentuessaan voisi sisällyttää opetusohjelmaansa myös sosiologian ja sosiaalipsykologian.

Kansansivistysopin ensimmäiseksi professoriksi nimitettiin vuonna 1946 fil. tri Urpo Harva, joka hoiti tointaan aina 1970-luvun alkuun saakka. 1970-luvulla alettiin niin Helsingin kuin Jyväskylän yliopistossa opettaa aikuiskasvatusta. Helsinki sai professuuriinsa 1980-luvun alussa, muut yliopistot 1990-luvun alussa (Jyväskylän, Turun, Lapin, Joensuun yliopistot sekä Åbo Akademi). Alan opetus on nykyisin levinnyt kaikkiin kasvatusalan opetusta antavaan yliopistoihin. Näin pitää ollakin, kuuluuhan aikuiskoulutus nykyisin kaikkien yliopistojen toiminta-alueisiin. Lisäksi meillä on valtava yleissivistävän, ammatillisen koulutuksen ja harrastusopintojen kenttä.

Jos ns. arkipäiväoppiminen (työssä, toiminnassa, kokemuksen kautta tapahtuva) otetaan huomioon - kuten maailmanlaajuisesti tehdään alan tutkimuskenttä laajenee inmisten jokapäiväiseen kasvuun, kehittymiseen ja oppimiseen. Yleensä jos jokin yhteiskunnallisesti merkittävä 
kenttä laajenee riittävästi, sille tarvitaan omat, alaan erikoistuneet ammattilaiset ja tutkimustietoa alan kehittämiseen.

Alan tutkimus Suomessa on laajaa ja monipuolista. Se kattaa niin erilaisissa aikuiskoulutusinstituutioissa, työssä, yhteiskunnallisessa toiminnassa ja arkipäivässä tapahtuvan oppimisen. Myös menetelmälliset lähestymistavat ovat moninaistuneet. Käytössä ovat mm. erilaiset toiminnan kehittämiseen tähtäävät toimintatutkimukselliset lähestymistavat. Myös toiminnan ymmärtämiseen tähtäävät biografiset, etnografiset, diskursiiviset ja muut laadullisen tutkimuksen lähestymistavat ovat varsin yleisiä. Näyttää siltä, että myös alan historian tutkiminen on jälleen nousussa, samoin perinteinen kansalaiskasvatus.

Sen sijaan nykyisin näkee yhä vähemmän kunnollista empiiristä tutkimusta. Lähinnä perinteinen osallistumistutkimus edustaa edelleen sitä, mutta se on pitkälti luovutettu Tilastokeskuksen suhteellisen teknisluonteisille ja kuvaileville selvityksille.

Maailman kansainvälistyessä suomalaiset ovat hämmästyksekseen huomanneet pärjäävänsä hyvin monikansallisissa tilaisuuksissa. Olemme melko hyvin perillä muiden maiden tilanteesta. Tosin saksankielen osaaminen on nykyisin vähäistä. Suurten kielialueiden tutkijat yleensä osaavat muitakin kieliä kuin omaansa, mutta olen huomannut, etteivät he viitsi juurikaan seurata muuta kuin omankielistä kirjallisuutta. Suomalaisten kiinnostus ja teknologiaosaaminen auttavat meitä selviytymään myös ulkomaisten kollegojen kanssa. Eli kun perusvalmiudet ovat olemassa, on helppo tulla toimeen muuallakin.

\section{Työelämän aikuiskoulutuksen (oppimisen)} tutkimusta pitäisi suunnata - erilaisten kehittämisprojektien lisäksi - entistä enemmän kriittiseen sosiologiseen ja sosiaalipsykologiseen tutkimukseen. On vaara, että aikuiskasvatuksen tutkimuksesta tulee vain työelämän kehittämisen uusi tehostamis- ja hiostamisväline tavoiteltaessa kansainvälistä huippua. On kysyttävä, onko se sen arvoista.

Meillä on maailman korkeimmat aikuiskoulutuksen osallistumisluvut, mutta myös burn out, stressi ja masennus ovat maailman huippua. Aikuiskasvatustutkimuksessa pitäisi panostaa enemmän siihen, miten aikuiskasvatusta/oppimista voidaan käyttää inhimillisemmän yhteiskunnan ja työelämän rakentamiseen niin, että opiskelu edistäisi mahdollisimman pitkälti aikuisten omia kehittymispyrkimyksiä. Ongelmana lienee se, että viime aikoina tutkimusrahoitusta on ollut helpointa saada sellaisiin työelämän kehittämishankkeisiin, joiden arvellaan parantavan yritysten asemaa kansainvälisessä kilpailussa. Muut saavat sen, mitä jäljelle jää, yleensä jaettavaa ei juuri jää.

Meilläkin on vihdoin opittu kohdentamaan resursseja tiettyjen ongelmaryhmien opiskelumahdollisuuksien parantamiseen (useimmiten tosin Ruotsia matkimalla), mutta projektien seurausvaikutusten tieteellinen tutkiminen ja sen kunnollinen resurssointi on vähäistä. Kehittäminen ilman tutkimusta jää kertapanostukseksi. Tutkimuksen avulla saatavan tiedon avulla hyöty on laaja-alaisempi ja pysyvämpi.

Tarvittaisiin monitieteistä tutkimusta inmisen oppimisesta elämänsä aikana. Nyt kiinnostus oppimiskysymyksiin on laajaa ja sitä tutkitaan monella eri tieteenalalla. Näissä tutkimuksissa ihminen tulee paloitelluksi työntekijäksi, organisaation jäseneksi, kansalaiseksi ja poliittiseksi toimijaksi, kuluttajaksi, aikuiseksi, perheenjäseneksi jne. Täytyisi palata elämänpoliittiseen näkökulmaan ja tarkastella ihmisten kasvua, kehitystä ja oppimista niissä elämänympyröissä, joissa he toimivat.

Samoja asioita tutkitaan eri tieteenaloilla hiukan erilaisin kysymyksenasetteluin ja käsittein. Esimerkiksi termeillä refleksiivinen, reflektiivinen, itsesuuntautunut, kriittinen, itsekasvatus, omaehtoinen, uusintaminen, aktiivinen tavoitellaan pitkälti samaa asiaa, ihmisen tulemista tietoiseksi omasta itsestään ja yhteiskunnan aktiiviseksi jäseneksi. Tarvittaisiin syvällisempää tutkimusta tästä prosessista ja sen yksilöllis-yhteiskunnallisista esteistä ja edellytyksistä. Tämä edellyttää perinteistä laajempaa, vallitsevaan kulttuuriin perustuvaa opiskelu- ja oppimisnäkemystä.

Päätoimittaja Juha Sihvonen totesi AIMA-lehden pääkirjoituksessa, että meillä on oppimista monesta eteläeurooppalaisesta maasta, lähinnä niiden ruohonjuuritason toiminnasta ja aikuisten aktiivisesta rekrytoinnista. Vaikka kulttuurit ovat erilaisia, olen samaa mieltä. Suomalaisten aikuiskasvattajien pitäisi jalkautua enemmän kentälle ja käynnistää siellä erilaisia projekteja ihmisten omista tarpeista, ei vain odottaa heitä opistoihin ja opintotilaisuuksiin. Jossain määrin näin tapahtuu, mutta edelleen liian vähän. Meillä on totuttu siihen, että kunhan tarjonta on mo- 
nipuolista ja näyttävää, se riittää. Se riittääkin osalle väestöä, mutta osa jää edelleen ulkopuolelle. Syystä tai toisesta heitä ei saa hevin tällaisiin valmiiksi ohjelmoituihin opetustilaisuuksiin. Tässä olisi tutkijoille ja käytännön työntekijöille yhteisen savotta. Hakevan toiminnan aakkoset pitäisi kai kaivaa taas esiin. Tai kehittää jotain vastaavaa uutta, tähän päivään paremmin sopivaa.

Tarvitaan muutosta myös yliopisto-opetukseen, se on liian instituutiokeskeistä. Monessa eurooppalaisessa yliopistossa aikuiskasvatuksen opiskelijat osallistuvat huomattavasti enemmän jo opiskeluaikanaan erilaisiin kenttäprojekteihin.

3 Ensin täytyisi määritellä sana itsenäinen. Luulen, ettei mikään tieteenala voi sanoa olevansa täysin itsenäinen. Tieteiden rajat ovat pitkälti sopimuksenvaraisia ja tiettyyn rationaliteettiin perustuvia. Ne voivat - ja oikeastaan niiden pitää muuttua ajan ja käytännön mukana. Aikuiskasvatus alkoi käytäntönä rahvaaseen kohdistuvana kansanvalistuksena, monien vaiheiden jälkeen olemme tilanteessa, jossa kohteena on koko kansa ja opetus vaihtelee tasollisesti peruskoulutuksesta yliopistollisiin ohjelmiin. On selvää, että tutkimuksen on täytynyt myös muuttua kehityksen mukana.

Aikuiskasvatusta voi pitää siinä mielessä itsenäisenä tieteenalana, että se on nykyisin Suomessa omana oppiaineena useammassakin yliopistossa, sillä on oma yli lähes 70-vuotias tieteellinen yhdistys (ATS), sillä on oma tieteellinen lehtensä, jossa tiedotetaan alan tutkimuksesta ja käydään avointa keskustelua aikuisten oppimiseen liittyvistä ongelmista, alalla tuotetaan omia oppikirjoja ja tutkimuksia jne. Kaiken lisäksi aikuiskasvatuksen tutkijat muodostavat suhteellisen selkeän kansainvälisen yhteisönsä, jolla on omat organisaationsa ja pitkäaikaiset perinteet muun muassa alan tieteellisten konferenssien järjestämisessä.

Edellä olen luetellut tieteellistymisprosessin sosiaalisia tuntomerkkejä, joita on yleensä käytetty tieteenalan "itsenäisyyden" peruskriteereinä. Tärkeintä on kuitenkin tieteenalan oman teoriarungon kehittyminen. Aikuiskasvatuksen ongelmia voi tutkia, ja myös tutkivat monen muunkin alan tieteenharjoittajat, ja hyvä niin. Aikuiskasvatusta tämä tutkimus hyödyntää kuitenkin vain siinä määrin, kun tämän tutkimuksen tulokset osataan liittää aikuiskasvatuksen omaan teo- riarunkoon. Myös aikuiskasvatuksen viranhaltijat voivat tutkia asioita liittämättä tuloksiaan mitenkään aikuiskasvatuksen teoriarunkoon.

Onko tällaista teoriarunkoa missään, ja jos on niin missä se voidaan havaita? Kuinka yhtenäistä ja solidia teoriarunkoa tällainen soveltava tieteenala kuin aikuiskasvatus tarvitsee? Jotkut aikuiskasvatustutkijat ovat kautta aikojen tuskailleet aikuiskasvatuksen epäitsenäisyyttä, eli sitä, että alan tutkijat ovat lainanneet tutkimustensa lähtökohdaksi jonkun muun tieteenalan teorioita. Toiset (ks. Jensen 1964; London 1964) ovat nähneet luonnollisena, että aikuiskasvatus koostaa teoriaansa a) analysoimalla käytännön toiminnasta saatuja kokemuksiaan ja b) käyttämällä muiden tieteenalojen tuloksia oman teoriarunkonsa rakentamiseen. Se tapahtuu lainaamalla ja uudelleen muotoilemalla nämä tulokset omiin tarkoituksiin sopiviksi. Tämä käytäntö on yleisesti hyväksytty myös kansainvälisesti ja se jatkuu edelleen (ks. Peters et al. 1991). Voidaan tietysti kysyä, missä määrin suomalaisessa aikuiskasvatuksessa on näin tapahtunut.

Nähdäkseni meillä on varsin hyvin ymmärretty muiden (perus-)tieteenalojen merkitys alan tutkimusongelmien ratkomisessa, mutta sen sijaan oman tutkimuksen liittäminen aikuiskasvatuksen teoriarunkoon ei ole aina tapahtunut kovin selkeästi ja tietoisesti. Eikä sitä ole aina edes tavoiteltu. Tätä voi pitää suomalaisen aikuiskasvatustutkimuksen heikkoutena, koska tällöin harjoitettu tutkimus ja siitä saatu tieto ei ole kiinnittynyt niinkään aikuiskasvatukseen, vaan johonkin toiseen tieteenalaan.

Jotta tällainen tutkimus tulisi paremmin kaikkien alan ihmisten käyttöön, pitäisi sitä siis tarkastella myös tietoisesti aikuiskasvatuksen ongelmakentän näkökulmasta. Meillä on esimerkiksi paljon sellaista aikuisten oppimista koskevaa tutkimusta, jossa kohderyhmänä ovat aikuiset, mutta tutkimuksessa ei tarkastella mitenkään, mitä heidän ikänsä ja aikuisuuteen liittyvät tehtävänsä ja roolinsa vaikuttavat heidän mahdollisuuksiinsa opiskella ja oppia. Tällainen tutkimus ei juurikaan lisää aikuiskasvattajien tietämystä oman työnsä edellytyksistä.

Aikuiskasvatustutkijat ovat siis aina korostaneet yhteistyön tärkeyttä muiden tieteenalojen tutkijoiden kesken. Aikaisemmin tämä saattoi johtui ainakin osittain siitä, että alan omia tutkijoita oli melko vähän. Tänä päivänä tilanne on ehkä hiukan toinen, yhteistyön tarve syntyy 
enemmän todellisesta monitieteellisen tutkimuksen tarpeesta. Tämä johtuu toisaalta nykyisten tiederajojen "vanhentumisesta", toisaalta verkostoitumisen tarpeesta. Siihen nykyteknologia antaa hyvät mahdollisuudet.

Verkostoituminen on tärkeää siksi, että nykyiset yhteiskunnalliset (aikuiskasvatukselliset) ongelma-alueet eivät rajaudu perinteisellä tavalla. Esimerkiksi perinteinen aikuiskasvatustutkimus ei olisi lainkaan kiinnostunut työssä ja/tai muussa yhteiskunnallisessa yhteydessä tapahtuvasta oppimisesta, koska aikaisemmin ajateltiin, että vain institutionaalinen aikuiskasvatustoiminta kuuluu alan tutkimuksen piiriin. (ks. Rubensson 1982, "Territory of Map"). Perinteinen kansansivistystyö/aikuiskasvatus ei ollut myöskään kiinnostunut työelämän koulutuksesta ja/ tai oppimista, koska aikuiskasvatukseen katsottiin kuuluvan vain aikuisten omaehtoisen, tutkintoon tähtäämättömän opiskelu.

Käsitys tieteiden rakenteista on nähdäkseni nykyisin joustavampi kuin aikaisemmin, vaikka erilaisia portin- ja reviirinvartijoita varmasti riittää. Itse olen havainnut, että eri tieteenaloilla on paljon yhteisiä tutkimusintressejä ja jopa päällekkäistä tutkimusta, vaikka kukin kuvittelee kamppailevansa yksin ainutlaatuisten ongelmien parissa. Tarvittaisiin tutkijoiden yhteisiä keskusteluareenoita tai -toreja, joissa voitaisiin keskustella eri tieteenalojen edustajien kanssa, mikä ketäkin mietityttää ja miksi.

4 Ainakin jo noin parikymmentä vuotta sitten keskustelimme Kjell Rubensonin kanssa mahdollisuudesta perustaa englanninkielinen pohjoismainen aikuiskasvatusjulkaisu "Acta Sosiologian" mallin mukaan, mutta keskusteluksi se jäi. Olen edelleen sitä mieltä, että tällaisella aikakauslehdellä olisi kansainvälistä tilausta. Muodostavathan Pohjoismaiset hyvinvointivaltiot edelleen eräänlaisen aikuiskasvatuksen mallialueen maailmassa, mitattiinpa asiaa sitten melkein millä mittarilla tahansa.

Ongelmana olisi Suomen osalta kilpailutilanne LLine'n kanssa. Mutta jos uusi lehti olisi selvästi tiedelehti, kilpailua ei kenties syntyisi.

Kilpailu tiedelehtien kesken on tänä päivänä kovaa. Kun lisäksi otetaan huomioon uusi teknologia, ongelma mutkistuu. Tai sitten lehdestä olisi heti alun alkaen tehtävä verkkolehti. Mielestäni kuitenkin kannattaa tarkkaan miettiä, kannattaako lähteä tässä vaiheessa uusiin hankkei- siin. Suomi tekee nähdäkseni jo enemmän kuin sen koon ja aseman perusteella voidaan vaatia. Pohjoismaista yhteistyötä kannattaa kuitenkin ylläpitää ja kehittää. Maailmalla se on se yhteisö, johon meidän on kaikkein helpointa samaistua.

Tartuin ensin tuohon pohjoismaiseen, vaikka kysymyksen pääpaino on eri yliopistojen yhteistyössä tiedelehden toimittamisessa. Päätoimittajuuden ja lehden toimittajuuden kierrättäminen on hyvä asia monestakin syystä. Se toisi uusia inmisiä lehden piiriin ja toivottavasti myös uusia kirjoittajia. Tällöin työ ja vastuu jakautuisivat tasaisemmin eri yliopistojen kesken.

Toimituksellinen vastuu on ollut tähän saakka Kansanvalistusseuralla, mikä on edelleen hyvä ratkaisu. Päätoimittaja tarvitsisi kuitenkin "työrukkasta" lähempää. Jos laitoskierto toteutuu, silloin olisi hyvä, että laitokselta joku nuorempi assistentti tai tutkija osallistuisi aktiivisesti myös lehden toimittamiseen.

\section{Lähteet}

Jensen, G. (1964). How Adult Education Borrows and Reformulates Knowledge of other Disciplines. Teoksessa Jensen, Liveright \& Hallenbeck (eds.), Adult Education. Outlines of an Emerging Field of University Study. Washington D. C. : Adult Education Association of the U. S. A. , 105-111.

London, J. (1964). The Relevance of the Study of Sociology to Adult Education Practice. Teoksessa Jensen, Liveright \& Hallenbeck (eds.), Adult Education. Outlines of an Emerging Field of University Study. Washington D. C.: Adult Education Association of the U. S. A., 113-136.

Peters, J. (1991). Advancing the Study of Adult Education: ASummary Perspective. Teoksessa Peters et al (eds.), Adult Education. Evolution and Achievements in a Developing Field of Study. San Francisco: Jossey-Bass Publishers, 421-446.

Rubenson, K. (1982). Adult Education Research: In Quest of a Map of the Territory. Adult Education, 1982, 32 (2), 57-74. 


\section{Nuorten aikuisten juurettomuus ja syrjäytyminen yhdeksi polttopisteeksi}

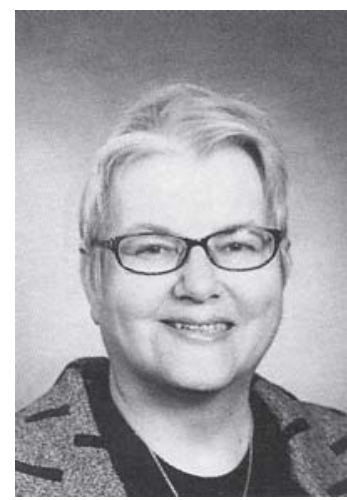

1 suomalainen aikuiskasvatustiede on suuntautunut erityisesti työssä oppimiseen, ja sillä saralla se on saavuttanut erityisiä ansioita. Työssä oppimiseen on kytkeytynyt myös työn kehittäminen (mistä tietysti työnantajatkin ovat mielissään). Työssä oppimisen edistämiseen tarvitaan ehdottomasti aikuiskasvatustieteilijöiden panosta oppimistapahtumien esiin nostajana, tukijana ja tutkijana.

2 Aikuiskasvatustieteessä tulisi avata työ-käsittettä siten, että siihen mahtuu myös kotona tehtävä työ ja vapaaehtoistoiminta. Jos työ kytketään tiukasti vain ansiotyöhön, esimerkiksi työttömätja eläkeläiset ja heidän elämismaailmansa putoavat pois tutkimusaiheiden joukosta, mikä on minusta tärkeä eettinen kysymys. Joensuun perspektiivistä käsin puutteita ja tarttumapintaa löytyy erityisesti vapaan sivistystyön alueella. Myös nuorten aikuisten juurettomuus ja syrjäytymisvaaran torjuminen kohdataan täällä tavallaan kipeämmin kuin Helsingissä. Koska oppiaineryhmässä painotetaan muun muassa kasvatusfilosofiaa, se näkyy aihevalintoina, kaikkialla se ei ole yhtä keskeinen. Klassikot esiin!

3 Aikuiskasvatustiede on oma tieteenalansa, sillä jos pidämme oppimista elämänikäisenä (lifelong learning), aikuisuus kattaa tästä elämäniästä varsin suuren osan. Lapsuus ja nuoruus ovat lyhyitä, mutta tärkeitä jaksoja oppimisen kannalta. Aikuisten oppimista taas estävät monet tekijät, jotka ovat vähitellen voitettavissa. Jos oppiminen kytketään mezirowilaisittain erityisesti elämän muutoskohtiin, niitäkin ehtii aikuisuudessa tulla useita. Reflektiivisen ajattelun ja ko- kemisen kyky on vasta aikuisella käytettävissä, ja se onkin osa aikuisten oppimista.

Olen edellä puhunut tarkoituksella oppimisesta. Pidän sitä aikuiskasvatustieteen yläkäsitteenä; kasvatus, koulutus ja ohjaus ovat oppimista edistäviä toimenpiteitä ja siten siis oppimisen palveluksessa. Aikuiskasvatus kytkeytyy moneen sisältöalueeseen, ja se tuo aikuisen näköalan monialaisiin erilaisiin hankkeisiin. Hyvä esimerkki on osaamiskeskittymät, joihin minua on pyydetty täällä Joensuussa: ne koskevat kieltä ja kulttuuria sekä kestävää kehitystä ja luonnontieteitä. Molemmille aikuiskasvatustieteellä olisi annettavaa-toki myös saatavaa!

4 Aikuiskasvatus-lehti on minusta hyvä nykyisessä muodossaan. Teemanumeroita ei pidä olla liikaa = nykyistä enempää niin, että kaikki aikuiskasvatuksen kukat pääsevät kukkimaan.

En kannata yhteispohjoismaisen tieteellisen aikakauskirjan perustamista - perustelen asiaa opetuksen(kin) näkökulmasta, sillä opiskelijoiden on hyvä tutustua suomalaiseen aikuiskasvatukseen myös sellaisenaan. Entä Nordisk Pedagogik? Voisivatko aikuiskasvatustieteilijät olla aktiivisempia myös sitä kohtaan?

Ensimmäinen askel olisi esitellä kaikki tutkimushankkeet, joissa on Suomen lisäksi muita Pohjoismaita. Niitäkin lienee runsaasti menossa.

\section{Teologian tohtoriksi}

$\mathrm{KT}$, vt. professori Leena Ahteenmäki-Pelkonen väitteli 10. marraskuuta teologian tohtoriksi väitöstutkimuksellaan Mikä ohjaa kirkon työnohjaajaa? Tutkimuksessa Ahteenmäki-Pelkonen haki kirkon ja psykiatrian työnohjaajien teoreettisia lähestymistapoja ja vertaili niitä keskenään. Kirkon työnohjauksessa keskeisiksi nousivat psykodynaaminen teoria, lähimmäiskeskeisyys, pastoraalipsykologia ja systeemiteoria. Vastaväittäjänä oli professori Kari E. Nurmi. 